\title{
The Realization of a Strong Trade Power and China's Direct Investment in SCO Countries
}

\author{
Lei Shen* \\ Shanghai University of Political Science and Law, Shanghai 201701, China \\ *Corresponding author: Lei Shen, shenlei@shupl.edu.cn
}

Copyright: ( $) 2022$ Author(s). This is an open-access article distributed under the terms of the Creative Commons Attribution License (CC BY 4.0), permitting distribution and reproduction in any medium, provided the original work is cited.

\begin{abstract}
China's path to becoming a strong trade power can be divided into three levels: the micro level of promoting factor cultivation, the meso level of achieving industrial dominance, and the macro level of participating in the establishment of the world system. As a feature of globalization, factor flow is the foundation and key to achieve the above three-level goals. In the first stage of reform and opening-up, China complied with the globalization characteristics of factor flow and gathered a large number of capital factors. It is now the second stage of reform and opening-up; that is, the stage of export-oriented investment. International investment may help in the path to become a strong trade power, or it may become an obstacle. The maximization of benefits and evasion of disadvantages are influenced by the grasp of investment risks. Therefore, special attention should be paid to identifying potential risks and controlling risks.
\end{abstract}

Keywords: Factor flow; Strong trade power; Shanghai Cooperation Organization; Investment risk

Online publication: February 23, 2022

\section{Introduction}

In 2013, China has surpassed the United States as the world's largest trading nation in goods, proving that in the first stage of development after reform and opening-up, China has achieved the goals of poverty eradication and economic power. At present, it is in the second stage, which is a new stage for China to explore transformation from a large trading nation to a strong trade power. It is certain that China will achieve the goal of becoming a strong trade power through foreign investment, which is closely related to the advancement of globalization. The current globalization has evolved from trade liberalization to investment liberalization; that is, international factor cooperation in the sense of factor flow. While conforming to the development direction of globalization, China has cultivated demand based on its own factors and explored the road to becoming a strong trade power through investment-driven trade.

In September 2013, a new stage has opened up for the development of China's outbound investment. In recent years, the SCO focus gradually shifted to building economic platforms, strengthening investments, and supporting value investment programs as well as conditions suitable for establishing industrial parks. All of these contribute to creating trade and investment. The formation of the international capacity of qualified bureau and the exploration of the new stage are not only the Chinese trade patterns, but also ways of realizing China's trade power. Since 2013, the enthusiasm of Chinese enterprises to venture abroad has been rising, and the ways as well as channels of outward direct investment have been diversified. In 2015, China's foreign direct investment volume exceeded the inflow of foreign capital for the first time, and China became the second largest foreign investment country in the world. Chinese enterprises with "going global" strategy have become the impetus for domestic economic transformation and upgrading as well as 
industrial structure adjustment. At the 11th China International Fair for Investment and Trade held in November 2019, more than 110 participating countries and regions were involved in a heated discussion under the theme of "High-Quality Cooperation for Prosperous Outbound Investment." The participants agreed that China's outward foreign direct investment is an important facet for promoting the development of China and the world itself. Comparatively speaking, the economic development of the countries in the SCO region is still at a relatively early stage, and the domestic capital stock is generally low. The effective countermeasure to solve this problem is to introduce foreign capital and produce projects in line with domestic advantages. The flow of international capital elements will not only fill the domestic capital gap, but also promote the long-term development of the host country's economy in view of the technical knowledge and other spillover effects brought by foreign capital. China's path of reform and opening-up over the past 30 years has set a good learning precedent for all developing countries. SCO countries can rely on the advantages of regional cooperation platforms to achieve the goal of successful transformation from "double gap" countries.

\section{Connotation of trade power and the characteristics of China's investment in SCO countries}

\subsection{Factor flow and the concept of trade power}

Factor flow makes it rare for a country to develop a complete industry by itself ${ }^{[1]}$. While opening their own market, most countries participate in the division of labor in the global value chain with their own set of factors. Factor mobility can be divided into strong and weak according to different factors of production. Factors such as capital, technology, and management have strong mobility, whereas those such as labor force, especially low-end labor force, have weak mobility, and some factors such as land cannot even flow at all. In that case, it is natural that foreign capital flows into China, and not the other way around.

China rose to the world's largest exporter of goods in 2009 and achieved the world's largest two-way total import and export volume in 2013. Undoubtedly, China is a major trading country, which reflects the great achievements of China after years of adhering to the concept of reform and opening-up. It is important to take note that major trading countries only make statistics at the level of trade scale. Without factor flow, the size of trade scale can still represent a country's foreign trade competitiveness. However, in the current era of globalization, international factor flow is the basis and feature of the operation of the world economy. From this point of view, trade scale is no longer suitable as a proof of a country's foreign competitiveness

${ }^{[2]}$. China's status as a major trading country was formed under special conditions. From the founding of New China to the reform and opening-up, China's domestic economic development level was low, and a large number of low-end labor and land could not be effectively utilized due to the lack of capital factors. On the contrary, western developed countries have completed capital accumulation and are completing the allocation of capital factors in the global range through multinational companies, so as to obtain excess returns. In the early stage of reform and opening-up, China was faced with the issue of double gaps, but globalization, the international flow characteristics of factors, did not allow it to wait for the accumulation of domestic capital factors to a certain extent before opening up. Instead, the development strategy was to introduce foreign capital, combine domestic labor, land, and other factors, as well as develop export processing trade under the guidance of foreign multinational corporations. The export processing trade mode guided by foreign capital ensues the participation of China in the division of labor in the international value chain with low-level factors, ranking China first in the world's export volume in a statistical sense.

\subsection{Factor cultivation and the connotation of trade power}

Just as there are differences between strong and weak mobility of production factors, there are also highlevel and low-level production factors. High-level factors, such as capital and technology, are relatively 
few in quantity and have high value, whereas low-level factors are on the contrary. Simple labor and other factors have large numbers but low value. Due to their scarcity, high-level elements will earn higher returns in the division of labor in the value chain, which is determined by the essence of economics [3]. Correspondingly, the returns of low-level elements are much lower than those of high-level elements. Therefore, in the division of labor in the international value chain dominated by multinational corporations, high-level elements occupy the high-end position, while low-level elements occupy the low-end position.

The inflow of foreign capital has put cheap labor and unused land to effect in China, which is also the key to China's development of foreign processing trade. Although China has become a major trading country, it is in fact participating in the division of labor in the international value chain with low-end factors. Labor and land factors do not occupy any advantage in the international division of labor. On the contrary, although a large number of labor and land factors are invested, the actual benefits of these two factors of production are far lower than those of foreign capital inflow. In fact, this is also the purpose of foreign investment led by multinational corporations, in which China will be included in the low-end division of labor in the international value chain. Conforming to mechanism of factor flow in the era of globalization, China has accumulated a large number of capital factors from the last round of reform and opening-up, changing from "double gap" to "double surplus," but the price paid is the induced distortion of factor prices. Specifically, China participates in the division of labor in the international value chain with labor factors and land factors lower than the normal price. The so-called labor dividend that China has owned for a long time is a false phenomenon caused by the lowering labor price, that is the wage level, below the normal price in the labor market; in fact, the comparative advantage of labor factors is also based on it. When attracting foreign capital inflows, local governments have taken preferential land prices as their own advantages, but this preferential land policy for foreign capital has seriously distorted land prices. In addition, the neglect of environmental factors also results in the underestimation of the price of this factor and even causes considerable irreversible environmental damage. This series of factor price distortions have brought down China's overall trade income.

In the process of China's trade transformation from big to strong, the top priority is to complete the cultivation of high-level factors. To be sure, the spearhead that China's factor income is pulled down and factor price is distorted points to an essential reason; that is, the lack of high-level factors. Therefore, in the future, it is necessary to speed up the cultivation of factors, realize technological innovation through scientific research, and cease the situation of participating in the division of labor in the international value chain with low-level factors. The realization of high-level elements participating in cooperation and leading division of labor will also bring benefits to China, which is the connotation and foundation of building a trade power.

\subsection{Factor cooperation and the characteristics of China's investment in SCO countries}

In the first stage of reform and opening-up, China complied with the globalization characteristics of factor flow and gathered a large number of capital factors. At present, it is entering the second stage; that is, to achieve high-grade factor returns through factor cultivation, which is not only the connotation of trade power, but also the law of global economic development. The new round of China's foreign direct investment marked by the Shanghai Cooperation Organization will boost private capital through state capital, forming a combination of Chinese capital factors and other countries' advantageous production factors, resulting in projects. The way of international production capacity cooperation is undoubtedly a new path to achieve trade power.

In recent years, the focus of SCO's work has gradually expanded from security issues to strengthening regional economic development. The expanded SCO has become an important platform for the construction of the Chinese international trade and investment, ushering in a new era of cooperation between China and 
SCO countries. China's infrastructure investment in SCO countries is mainly in the form of project cooperation. Specifically, it is funded by China, and construction engineering teams are directly transferred. Therefore, it can be said that China's advantageous elements include capital elements, construction technology elements, and skilled labor elements of construction engineering. The first thing to consider in infrastructure construction is its location. Whether it is a road, railway, or hydropower station, its geographical location is based on the land elements of a specific location. Therefore, it can be said that the advantageous element of the host country is the land element with special location value. Through infrastructure investment projects, the capital, technology, and other advantageous elements from China will be combined with the advantageous land elements of the host country, so as to achieve deep-seated international cooperation in the sense of factor flow. As of today, China has established 56 economic and trade cooperation zones in the SCO region. The economic and trade cooperation zones emphasize on strengthening investment, supporting and attaching importance to investment planning, as well as creating trade with investment. This international cooperation, which goes beyond the constraints of a country's domestic factor endowment and industrial structure while breaking through the possibility of optimal allocation of domestic resources, has played the role of advantageous factors of various countries to a large extent as well as realized a more efficient and reasonable combination of advantageous elements of various countries. China's investment in SCO countries is essentially the further deepening of the second stage of reform and opening-up; that is, from the past one-way investment structure to the current two-way investment structure.

\section{China's investment risk in SCO countries under the strategy of trade power}

\subsection{The traditional foreign investment risk cannot explain the current Chinese foreign investment risk}

In previous literatures on the risk of foreign investment, a considerable number of scholars believe that information asymmetry is the main reason for the risk of foreign investment. The host government has the private information that investors lack. There is a game between them. One party can only make decisions based on the limited information collected about the other party; hence, the incomplete information may lead to decision-making mistakes. This information asymmetry between investors and host governments is the most common factor leading to the risk of foreign direct investment. Specifically, the current problems of Chinese investment in SCO countries include the following: the host country is worried that its own energy resources will be controlled by foreign capital and thus has resistance to foreign capital, whereas the investor country is unsure about the host country's attitude toward foreign investment; moreover, the government may make certain choices that are contrary to investors' expectations, such as announcing the confiscation of investment projects after the signing of the investment agreement, resulting in higher investment risks.

Although investment risk is emphasized, the foreign investment risk of China, in the prospect of becoming a strong trade power, is completely different from that of traditional western countries. The expansion of capital within the scope, the pursuit of interests, the maximization of its capital gains, as well as the low buying and high selling of the host country's advantageous elements are the basic characteristics of its foreign investment. China's foreign investment, in the prospect of becoming a strong trade power, is an international element cooperation that conforms to the development of globalization. In the past, many organizations founded in China creatively assume their projects as the foundation of regional economic construction, which reduces the complexity of regional co-construction and is more conducive to the interconnection and development of a certain region. Taking "mutual trust, mutual benefit, equality, consultation, respect for multiple civilizations, and seeking common development" as the principle of mutual relations among countries in the region, SCO emphasizes on strengthening investment, supporting 
and attaching importance to investment planning, creating trade with investment, as well as establishing economic and trade cooperation zones under appropriate conditions. Whether it is the former organization or SCO, China, as a responsible country, actively leads the development of other developing countries and uses the form of foreign direct investment to combine its advantageous elements with those of the host country to generate projects. Therefore, traditional international investment risk does not fit here.

It is believed that information asymmetry is the theoretical basis of China's investment risk in SCO countries, which lies in the zero-sum view ${ }^{[4]}$. The reason is that there are still some old conceptual prejudices against China's rise as an economic power in the world. It is undeniable that in some cases, the zero-sum game exists objectively between the two sides of the game, and neither side has created new benefits. At this time, the loss of one party is the gain of the other party. This view also extends to China, which is in the process of reform and opening-up. It holds that the huge economic benefits China has achieved in the process of reform and opening-up are the economic losses of other countries, damaging the interests of other countries, and transferring the economic benefits of other countries to China through its opening to the outside world, which has led some countries to doubt or even oppose China's reform and opening-up. In the face of much pressure, China has responded positively by showing the world that its development strategy and goal orientation have always been a win-win cooperation. The future development trend of China and other countries in the world is bound to be the international factor cooperation that conforms to the era of globalization. Factor cooperation is not only the micro basis for the economic development of all countries, but also a feature of the current world economy. The overall strategy of China's political and economic diplomacy in the new era, namely the win-win cooperation, is a macro strategy based on the micro basis of factor cooperation. Under the guidance of the win-win cooperation, all countries will achieve a positive sum game; that is, a win-win situation. It is not true that China's foreign investment risks are caused by information asymmetry at this stage.

\subsection{Risks of China's investment in SCO countries at the present stage}

\subsubsection{Factor price distortion}

In the process of reform and opening-up in the first stage, relying on its institutional advantages, China has attracted foreign capital inflows, formed a processing trade export industry dominated by foreign capital, and solved the issue of "double gap" in capital and foreign exchange ${ }^{[5]}$. However, in this process, an induced twist in factor prices has occurred. Due to the idleness of a large number of labor forces, the pricing of labor factors was too low at the beginning. This kind of labor pricing below the normal market level occurs not only in the low-end labor force, but also in the high-end labor force. For a long time, the labor dividend has been driving down the labor price, namely the wage level, to the normal price of the labor market. The land factor also faces a similar problem. The distortion of factor prices has brought down the overall economic benefits of China. In the second stage of China's opening to the outside world, it is very important to guard against the risk of factor price distortion and prevent this phenomenon. On the other hand, since it is an international investment with the international flow of capital factors as the carrier, it will be dominated by capital intensive industries. In recent years, the industry has experienced rapid development, which may be affected by high investment and high valuation. Therefore, this does not represent the actual value. Some enterprises may be eliminated prematurely in foreign markets because they do not have competitiveness, which will affect the overall benefits of China's international investment. Therefore, when China invests in SCO countries, special attention should be paid to the pricing of domestic factor market to reduce the risk of factor price distortion. 


\subsubsection{Factor cooperation trap}

The key conclusions to the connotation of trade power include the cultivation of high-level elements, the participation in the division of labor in the international value chain with high-level elements, and the realization of a high-end position of the division of labor in the value chain while obtaining higher returns. This is not only China's strategic policy to transform into a strong trade power, but also to avoid the risks brought by the factor cooperation trap. The issue with this reputed factor cooperation trap is that it has occurred in the past and will persist for a long time into the future to participate in the division of labor in the international value chain with low-end factors. One of the reasons for this situation lies in the overreliance on the theory of comparative advantage ${ }^{[6]}$. It is believed that the premise for a country to participate in international cooperation is its comparative advantage that other countries do not have, in addition to path dependence. In the absence of factor flow, a country may indeed participate in the international division of labor with its comparative advantage, but this assumption is not consistent with the current fact of international factor flow. China's international investment based on the principle of international factor cooperation has revealed the world's economic essence of factor flow. The entry point for countries to participate in the international division of labor is linked to advantageous factors rather than comparative advantage. Therefore, one of the potential risks that China may encounter when investing in SCO countries is the factor cooperation trap in terms of comparative advantage. The weight is that it has been at the low end of the division of labor in the international value chain for a long time.

\subsubsection{Relationship between the government and the market}

Experience has proven that the best strategy of the host country is to introduce foreign capital. There is no game, especially zero-sum game, between the investing country and the host country in China's investment in SCO. The intentions of the investors are clear and definite. From the perspective of a responsible country, the investor promotes international factor cooperation with the flow of capital factors as the carrier to meet the needs of the host country to make use of idle advantageous factors. The investment risk caused by information asymmetry between the two sides, which is an international investment risk in the traditional sense, does not match reality. However, it should be emphasized that in the development process of SCO, regional cooperation and co-construction are the ultimate goals. The host country cannot always rely on foreign investment from China. The top priority is to fill its scarce capital elements first, then slowly cultivate their hematopoietic ability, and finally realize regional co-construction ${ }^{[7]}$. The host country needs to make proper use of capital elements to promote its domestic economic development, so as to avoid the unhealthy situation of arranged cooperation. It can be said that the deep-seated reason for China's investment in SCO countries lies in the realization of a strong trade power, which has a profound impact on the relationship between the government and the market. Foreign investment requires the market to be more open and operate more efficiently. At the same time, it also puts forward high-level requirements for government departments. If the relationship between the government and the market is poor, the risk of the government completely controlling the market, or the risk of government inaction and relying only on the market mechanism may occur. Whether the government is offside or absent, there will be many potential risks in foreign investment. The SCO implements a project-first policy, in which government investment is given priority, while private investment is driven. It is necessary to grasp the degree of government functions to avoid the allocation of resources by the government rather than the market, which violates the nature of economic development. In the future, with the further development of international investment, the government's continuous commitment to the leading position of investment may be counterproductive and may disrupt the market balance. 


\section{Funding}

This paper is the phased achievement of the 2020 China-SCO International Judicial Exchange and Cooperation Training Base Research Fund Project, "Research on the Risk and Avoidance of China's Direct Investment in SCO Countries" (Project Number: 20SHJD025); the subproject of the Discipline Construction Project of the School of Economics and Management of Shanghai University of Political Science and Law in 2021 (Project Number: GH21004); that is, the phased achievement of the Economic Security Discipline Construction Project of Shanghai University of Political Science and Law, "Analysis on the Security and Liquidity of China's Outbound Investment"; and the phased achievement of the 2014 Youth Scientific Research Fund Project of Shanghai University of Political Science and Law (Fourth Batch), "Factor Flow and Construction of Silk Road Economic Belt" (Project Number: 2014XQN27).

\section{Disclosure statement}

The author declares no conflict of interest.

\section{References}

[1] Chen Y, 1997, Multidimensional Signaling and Diversification. The RAND Journal of Economics, 28(1): 168-187.

[2] Simoes AJ, Ventura J, Coelho LA, 2014, Foreign Direct Investment and Fiscal Policy - A Literature Survey, University of Evora, CEFAGE-UE Working Papers, Portugal.

[3] Kamin SB, von Kleist K, 1999, The Evolution and Determinants of Emerging Markets Credit Spreads In The 1990s, BIS Working Papers 68, Bank for International Settlements.

[4] Jennings M, 2016, The International Investment Regime and Investor-State Dispute Settlement: States Bear the Primary Responsibility for Legitimacy. Bus L Int'1, 17: 127.

[5] Thomas J, Worrall T, 1994, Foreign Direct Investment and the Risk of Expropriation. The Review of Economic Studies, 61(1): 81-108.

[6] Vandevelde KJ, 1998, The Political Economy of a Bilateral Investment Treaty. American Journal of International Law, 92(4): 621-641.

[7] Tezera K, 2018, Dynamics of Identity Formation and Legal Pluralism: The Case of Customary, State and Religious Dispute Resolutions Among the Siltie People, Southern Ethiopia. 